\title{
KADAR ANTOSIANIN, AMILOSA DAN ORGANOLEPTIK SNACK BAR KACANG MERAH PRATANAK DAN UBI UNGU SEBAGAI ALTERNATIF MAKANAN BAGI PENYANDANG DIABETES MELLITUS
}

\author{
Anthocyanin, Amylose and Organoleptic of Precooked Kidney Beans and Sweet \\ Potato Snack Bar as Alternative Food for People With Diabetes Mellitus
}

Fitriana Mustikaningrum, Hilda Carella, Anggraini Wulandari

Program Studi Ilmu Gizi, Fakultas Ilmu Kesehatan, Universitas Muhammadiyah Surakarta, Jalan Ahmad Yani, Pabelan, Kartasura, Surakarta 57162, Jawa Tengah, Indonesia

Corresponding author: fm250@ums.ac.id

\begin{abstract}
Abstrak
Latar Belakang: Pengaturan diet merupakan salah satu cara dalam mengendalikan kadar glukosa darah bagi penderita diabetes mellitus. Bahan makanan yang mengandung antosianin dan pati resisten lambat dicerna di dalam pencernaan, sehingga dapat membantu menjaga kadar glukosa darah. Snack bar kacang merah pratanak dan ubi jalar ungu merupakan salah satu alternatif makanan tinggi antosiain dan pati.

Tujuan: Penelitian ini bertujuan mengetahui proporsi terbaik tepung kacang merah pratanak dan ubi jalar ungu pada pembuatan Snack bar berdasarkan kadar antosianin, amilosa dan daya terimanya.

Metode: Penelitian ini menggunakan 3 variasi perbandingan kacang merah pratanak:ubi jalar ungu yaitu 10\%:90\%; 20\%:80\%; 30\%:70\%. Analisis antosianin menggunakan metode $\mathrm{pH}$ differential, sedangkan analisis amilosa menggunakan metode spektrofotometri. Uji organoleptik menggunakan uji hedonic test. Analisis statistik menggunakan uji One way ANOVA, apabila terdapat perbedaan yang signifikan diteruskan dengan uji Duncan Test dengan signifikansi P-value $<0,05$.

Hasil: Semakin tinggi proporsi ubi jalar ungu, maka semakin tinggi kadar antosianin dan amilosa pada Snack bar (P-value<0,01). Snack bar dengan proporsi 10\%:90\% secara signifikan lebih disukai panelis (P-value= $0,04)$.

Kesimpulan: Snack bar dengan proporsi10\%:90\% merupakan formula terbaik, dengan kadar antosianin dan amilosa tertinggi, dan lebih dapat diterima dibandingkan proporsi lainnya.
\end{abstract}

Kata Kunci: Snack bar, kacang merah pratanak dan ubi jalar ungu, antosianin, amilosa, organoleptik

\begin{abstract}
Background: Diet management is a solution to control blood glucose levels for people with diabetes mellitus. Food containing anthocyanins and resistant starch will be slowly digested in the digestive tract, thus, it can help maintain blood glucose levels. Snack bar from precooked kidney beans and purple sweet potato is an alternative food that is high in anthocyanin and starch.

Aim of Study: The purpose of this study was to investigate the best proportion of precooked kidney bean and sweet potato flours in Snack bar based on level of anthocyanin, amylose and organoleptic acceptance.

Method: The Snack bar was made from 3 variations of the ratio of precooked kidney beans: sweet potato; 10\%:90\%; 20\%:80\%; 30\%:70\%. Anthocyanin analysis was used differential $\mathrm{pH}$ method, while amylose analysis was used spectrophotometric method. The organoleptic test was used Hedonic test. The One-way ANOVA statistic test was analysed significant difference between variable, followed with Duncan Test with significancy at P-value $<0.05$.

Result: Higher proportion of purple sweet potato significantly enhanced the level of anthocyanin and amylose (P-value <0.01) and preferred by panellists (P-value $=0.04)$.

Conclusion: The Snack bar with proportion 10\%:90\% had the highest anthocyanin and amylose, also more sensory acceptable in comparation with 30\%:70\% and 20\%:80\%.
\end{abstract}

Key words: Snack bar, precook red beans and purple sweet potato, anthocyanin, amylose, organoleptic 


\section{PENDAHULUAN}

Prevalensi diabetes mellitus terus meningkat setiap tahunnya. Estimasi prevalensinya untuk usia dewasa (20-79 tahun), diperkirakan mencapai 6,4\% (285 juta) pada tahun 2010 dan diperkirakan akan meningkat sampai 7,7\% (439 juta) pada tahun 2030 (Shaw et al., 2010). Prevalensi diabetes mellitus pada usia produktif di perkotaan Indonesia sendiri mencapai $4.6 \%$ dengan jumlah lebih banyak pada wanita dibandingkan laki-laki (Laurentia et al., 2014).

Salah satu penyebab dari tingginya kasus diabetes mellitus adalah ketidak seimbangaan asupan makan, konsumsi makanan yang cenderung tinggi lemak, gula, dan rendah serat dapat menyebabkan peningkatan glukosa darah 2 jam postprandial (Franz et al., 2012). Selain dengan terapi farmakologis, terapi nonfarmakologis melalui pengaturan diet dengan pemilihan konsumsi makanan yang tidak menimbulkan peningkatan glukosa darah secara cepat merupakan salah satu cara dalam mengendalikan kadar glukosa darah (Laurentia et al., 2014).

Beberapa penelitian telah menunjukkan diet yang sehat dengan peningkatan konsumsi makanan tinggi antosianin terbukti dapat memperbaiki kondisi diabetes mellitus dengan komplikasi. Antosianin merupakan salah satu komponen bioaktif yang menjanjikan untuk melawan diabetes (Gowd et al., 2017; Jayaprakasam et al., 2017). Salah satu penelitian menunjukkan bahwa pemberian suplementasi antosianin pada tikus obesitas secara signifikan dapat menurunkan akumulasi lemak dan konsentrasi trigliserida di hepar, serta meningkatkan fungsi sel $\beta$ - pankreas (Sancho et al., 2012). Beberapa penelitian pada sel dan jaringan hewan coba juga menunjukkan bahwa suplementasi antosianin menurunkan senyawa oksigen reaktif (SOR) di mitokondria, sensitifitas insulin, gula darah puasa plasma, dan melindungi sel $\beta$ dari oksidatif stress (Acosta et al., 2016). Selain itu, antosianin menghambat aktivitas $\alpha$ - amilase dan $\alpha$ glucosidase pankreas di dalam lumen usus, kemudian berinteraksi dengan transporter glukosa 1 (GLUT1) dan transporter glukosa 2 (GLUT2) yang bergantung pada natrium untuk mengurangi laju pengambilan glukosa ke dalam sirkulasi darah, yang pada akhirnya dapat menurunkan gula darah prospandial (Eleazu, 2016).

Selain antosianin, konsumsi pangan dengan kandungan amilosa tinggi (>25\%) serta Indeks Glisemik (IG) rendah $(<55)$ mampu memperbaiki sensitivitas insulin pada penderita diabetes mellitus, menurunkan laju penyerapan glukosa, serta 
bermanfaat dalam pengendalian glukosa darah, sehingga dapat menurunkan risiko komplikasi (Gowd et al., 2017; Eleazu, 2016). Tingginya amilosa pada makanan dapat menurunkan daya cerna pati in vitro. Daya cerna pati yang rendah menentukan aktivitas hipoglikemik, karena dapat menghasilkan glukosa lebih sedikit dan lebih lambat. Insulin yang diperlukan untuk mengubah glukosa menjadi energy juga lebih sedikit, sehingga kadar glukosa didalam darah tidak mengalami kenaikan secara drastis. Sumber pangan dengan daya cerna pati yang rendah cenderung memiliki IG lebih rendah, sehingga lebih aman dikonsumsi untuk penderita Diabetes mellitus (Mustikaningrum, 2011; Eleazu, 2016).

Ubi jalar ungu (Ipomoea batatas L. Poir) adalah jenis umbi-umbian yang memiliki banyak keunggulan dibanding umbi lainnya karena memiliki IG terendah yaitu 44 dan karbohidrat utamanya adalah pati, terdiri dari 30-40\% amilosa (Nintami et al., 2012). Kadar antosianin ubi jalar ungu berkisar antara 3-61 g/100 g. Penurunan aktivitas antioksidan ubi ungu pada saat pengolahan makanan berbanding lurus dengan penurunan kadar antosianin (Husna et al., 2013).

Ubi jalar mengandung gula pereduksi, seperti fruktosa, glukosa, dan rafinosa yang ketika berikatan dengan asam amino, menghasilkan senyawa yangdapat menguap, sehingga menyebabkan penurunan kadar protein produk olahannya (Avianty dan Ayustaningwarno, 2013). Untuk mengatasinya, perlu penambahan bahan pangan lain yang berprotein tinggi. Penambahan kacang merah mampu meningkatkan kandungan protein pada Snack bar. Selain protein yang tinggi, kacang merah juga mengandung flavonoid dan serat (Shehzad et al., 2015).

Kandungan amilosa Snack bar berbahan ubi jalar ungu hanya $15 \%$, lebih rendah dibandingkan Snack bar ubi jalar merah dan kacang merah $(44,83 \%)$. Pati resisten dengan kadar amilosa yang tinggi lebih stabil dan lebih sulit dicerna daripada pati tinggi amilopektin (Avianty dan Ayustaningwarno, 2013; Ratnaningsih dan Marsono, 2013). Proses instanisasi atau pratanak dapat meningkatkan serat dan pati resisten pada kacang merah. Penelitian menunjukkan peningkatan serat pangan dan pati resisten, serta sifat hipoglikemik kacang kapri setelah melalui proses pratanak dibandingkan kacang kapri dengan perebusan (Mustikaningrum, 2011).

Berdasarkan latar belakang tersebut, maka perlu dilakukan penelitian untuk mengetahui potensi Snack bar dari ubi ungu dan kacang merah pratanak, 
sebagai makanan alternatif bagi penderita diabetes mellitus, berdasarkan kadar antosianin, amilosa, dan daya terimanya.

\section{METODE PENELITIAN}

\section{Desain dan Tempat Penelitian}

Penelitian eksperimen ini menggunakan rancangan acak lengkap. Penelitian ini dilakukan pada tahun 2016 di Laboratorium Pangan Universitas Muhammadiyah Surakarta dan Laboratorium Teknologi Pangan dan Hasil Pertanian Universitas Gadjah Mada Yogyakarta.

\section{Bahan dan alat}

Bahan baku yang digunakan dalam penelitian adalah ubi jalar ungu varietas lokal dengan warna kulit ungu pekat dan daging umbi ungu kehitaman, yang diperoleh di pasar sekitar Solo. Bahan kimia yang digunakan untuk analisis adalah methanol, aquades, etanol, HCL, $\mathrm{KCL}, \mathrm{NaOH}$, asam asetat (Merck, Jerman). Alat yang digunakan berupa neraca elektrik (SHIMADZU type LS-6DT), rotary evaporator (Heidolph WB 2000), oven Memmert 100-8--, Spektrofotometri UV-Vis (Spepctronic 20 Genesys TM), sentrifugator, aluminium foil

\section{Pembuatan Tepung Kacang Merah Pratanak, Tepung Ubi Jalar Ungu, dan Snack Bar Ubi Ungu}

Metode pembuatan kacang merah pratanak mengikuti prosedur Mustikaningrum (2011) dengan modifikasi. Proses pratanak kacang merah dilakukan melalui tahapan pencucian, perendaman dengan akuades selama 16 jam, dengan perbandingan air : kacang merah $=1: 2$. Selanjutnya, dilakukan pengukusan dengan suhu $100{ }^{\circ} \mathrm{C}$ selama 15 menit, kemudian dikeringkan menggunakan sinar matahari selama 40 jam. Penggilingan menggunakan grinder sehingga menjadi tepung yang diayakan menggunakan ayakan 80 mesh. Pembuatan tepung ubi jalar ungu meliputi pembersihan, pengupasan, pencucian, pengirisan, pemblanchingan selama 2,5 menit, dilanjutkan dengan pengeringan dengan sinar matahari selama 40 jam, pendinginan suhu ruang, pengggilingan, dan pengayakan 80 mesh (Hardoko et al., 2010).

Bahan yang digunakan dalam pembuatan Snack bar meliputi gula jagung, telur, susu skim, minyak nabati, butter, dan air. Bahan tersebut dicampur hingga rata, kemudian dilakukan penambahan tepung ubi jalar ungu dan tepung kacang merah pratanak, dicampur hingga kalis. Snack bar kemudian dicetak, 
dan dipanggang dengan suhu $230^{\circ} \mathrm{C}$ selama 30 menit (Amalia, 2011).

\section{Pengujian Kadar Total Antosianin,}

\section{Amilosa, dan Daya Terima}

\section{Pengujian Antosianin}

Pengujian berupa Snack bar diekstraksi dengan cara maserasi pada suhu $25^{\circ} \mathrm{C}$. Sebanyak $100 \mathrm{~g}$ Snack bar dimaserasi dengan $300 \mathrm{~mL}$ pelarut etanol pada suhu $25^{\circ} \mathrm{C}$ selama 24 jam, kemudian disaring dan diambil filtratnya. Pemilihan metode maserasi pada suhu $25^{\circ} \mathrm{C}$ karena metode ini menghasilkan rendemen dan total antosianin terbesar dibandingkan metode dengan metode maserasi $5^{\circ} \mathrm{C}$ dan soxhletasi (Suzery et al., 2010). Hasil ekstraksi disaring menggunakan kertas saring kasar, kemudian filtrat yang diperoleh diuapkan (evaporator vakum) pada $60 \mathrm{rpm}$ selama 1.5 jam. Filtrat pekat dimasukkan ke dalam cuvet diukur kandungan antosianinnya menggunakan metode $\mathrm{pH}$ differential, dengan $\mathrm{pH} 1$ dan 4,5. Absorbansi dibaca menggunakan spektrofotometer UV-Vis pada $510 \mathrm{~nm}$ (Wrolstad, 2001).

\section{Pengujian Amilosa}

Analisa Amilosa menggunakan metode Spektrofotometer (Apriyantono et al., 1998). Sampel sebanyak $100 \mathrm{mg}$, dimasukkan ke tabung dan ditambahkan 1 mL etanol 95\% dan 9 mL larutan $\mathrm{NaOH}$
1M, kemudian dipanaskan dengan penangas air pada suhu $95^{\circ} \mathrm{C}$ selama 10 menit hingga terbentuk gel. Seluruh gel dipindahkan kedalam $100 \mathrm{ml}$ dan diencerkan. Sebanyak $5 \mathrm{ml}$ larutan tersebut dipipet, dimasukkan kedalam labu takar $100 \mathrm{ml}$. Ditambahkan 1ml asam asetat 1M dan $2 \mathrm{ml}$ larutan Iod $0,2 \%$, lalu ditera dengan air destilata dan didiamkan selama 20 menit. Intensitas warna yang terbentuk diukur menggunakan spektrofotometer pada Panjang gelombang $625 \mathrm{~nm}$.

\section{Pengujian Organoleptik}

Uji kesukaan/organoleptic diawali dari snack bar dengan proporsi ubi jalar ungu dan kacang merah pratanak yang disukai (yaitu 80\%:20\%) yang dilakukan oleh 15 panelis semi terlatih. Hasil uji kesukaan ini kemudian digunakan sebagai acuan dalam melakukan penelitian dengan 3 perlakuan yaitu Perlakuan A (tepung kacang merah pratanak : tepung ubi jalar ungu 30\%:70\%), Perlakuan B (tepung kacang merah pratanak: tepung ubi jalar ungu 20\%:80\%), dan perlakuan C (tepung kacang merah pratanak: tepung ubi jalar ungu 10\%:90\%).

Uji daya terima pada Snack bar dilakukan oleh 30 panelis semi terlatih dengan pengujian variable meliputi warna, aroma, rasa, tekstur, dan kesukaan secara keseluruhan. 


\section{Analisa data}

Uji daya terima, kadar antosianin, dan kadar amilosa dianalisis menggunakan uji statistik One Way ANOVA menggunakan program SPSS versi 2.0, dengan nilai signifikansi $\mathrm{P}<0.05$. Jika terdapat pengaruh terhadap kadar amilosa, antosianin, dan daya terima, maka pengujian statistik dilanjutkan dengan uji Post hoct Duncan's Multiple Range Test (DMRT) pada taraf signifikansi $\mathrm{P}<0.05$.

\section{HASIL DAN PEMBAHASAN}

\section{Analisa Kadar Antosianin Snack bar}

Tabel 1 memaparkan pengaruh proporsi tepung kacang merah pratanak : tepung ubi jalar ungu terhadap kadar antosianin Snack bar. Semakin tinggi proporsi ubi jalar ungu, maka kadar antosianin pada Snack bar semakin tinggi. Kadar Antosianin Snack bar dengan proporsi kacang merah pratanak dan ubi jalar ungu 10\%: 90\%, secara signifikan memiliki kadar antosianin yang tertinggi $\quad(\mathrm{P}<0,01)$ dibandingkan proporsi lainnya.

Tabel 1.

Kadar Antosianin Snack bar

\begin{tabular}{ccc}
\hline $\begin{array}{c}\text { Proporsi tepung kacang merah pratanak:tepung } \\
\text { ubi jalar ungu pada Snack } \text { bar }\end{array}$ & $\begin{array}{c}\text { Rata-rata } \pm \text { SD } \\
(\mathbf{m g} / \mathbf{1 0 0} \mathbf{~ g})\end{array}$ & P-Value \\
\hline $30: 70$ & $79,69 \pm 0,63^{\mathrm{a}}$ & \\
$20: 80$ & $86,46 \pm 2,43^{\mathrm{b}}$ & $<\mathbf{0 . 0 1}$ \\
$10: 90$ & $90,74 \pm 0,49^{\mathrm{c}}$ & \\
\hline
\end{tabular}

$\mathrm{n}=$ jumlah ulangan, 4; Proporsi tepung kacang merah pratanak: tepung ubi jalar ungu dalam persen (\%).Uji statistic menggunakan One-way ANOVA, dilanjutkan dengan uji Post Hoc Duncan Test dengan huruf yang berbeda menunjukkan signifikansi pada $P$-value $<0,05$.

Hasil penelitian ini menunjukkan bahwa banyaknya proporsi ubi jalar ungu meningkatkan total antosianin Snack bar. Hal ini mungkin disebabkan kandungan antosianin pada ubi jalar ungu pekat lebih tinggi dibandingkan dengan kacang merah, yaitu $61.85 \mathrm{mg} / 100 \mathrm{~g}$, sedangkan kandungan antosianin pada kacang merah kering sebesar $7.21 \mathrm{mg} / 100 \mathrm{mg}$ (Sari et al., 2020; Husna et al., 2013). Pengolahan bahan makanan seperti pemanasan dan perendaman dapat mempengaruhi kadar antosianin. Penelitian menunjukkan bahwa perendaman selama 4 jam dilanjutkan dengan pengukusan dapat mengurangi kadar antosianin hingga $90 \%$ pada beras ungu (Yamuangmorn et al., 2018)). Proses penepungan kacang merah menurunkan kadar antosianin hingga 18\% (Sari et al., 2020). Hal yang sama juga mungkin terjadi pada pratanak kacang merah yang melalui proses perendaman dan pengukusan, sehingga menyebabkan pengurangan kadar antosianin yang cukup tinggi. Beberapa 
penelitian menunjukkan bahwa antosianin dari kelompok Petunidin yang memberikan warna merah tua hingga ungu pada tanaman, merupakan senyawa larut didalam air dan kurang stabil terhadap pemanasan suhu tinggi (Khoohock et al., 2017).

Snack bar dengan proporsi tepung kacang merah pratanak dan tepung ubi jalar ungu 10\%:90\% dengan kadar antosianin tertinggi memiliki potensi sebagai makanan yang baik bagi penderita diabetes mellitus. Antosianin dapat menghambat $\alpha$ - amilase dan $\alpha$-glucosidase dalam pencernaan yang menunjukkan bahwa senyawa tersebut lambat dicerna, sehingga mengurangi pembebasan dan penyerapan glukosa dalam usus. Karena itu, konsumsi tinggi antosianin dapat mengurangi resiko diabees mellitus, obesitas, dan penyakit kardiovaskular (Ratseewoa et al., 2019).

Penelitian menunjukkan bahwa kadar antosianin pada suatu bahan berbanding lurus dengan aktivitas antioksidannya (Husna et al., 2013;
Marniati et al., 2017). Snack bar dengan proporsi 10\%:90\% kemungkinan memiliki aktivitas antioksidan yang lebih tinggi daripada proporsi lain. Peningkatan kadar antioksidan yang disebabkan oleh supplementasi antosianin yang berasal dari tanaman berperan dalam pengikatan radikal bebas, penurunan radikal bebas yang disertai dengan peningkatan kadar superoksida dismutase (SOD) di hati pada tikus percobaan. Superoksida dismutase merupakan antioksidan intrasel yang melindungi sel terhadap gangguan oksidan. Guo et al. (2015) menyebutkan bahwa stress oksidatif dapat menyebabkan timbulnya penyakit degenerative, karena itu tingginya kadar atau aktivitas SOD dapat melindungi perkembangan Diabetes Melitus.

\section{Kadar amilosa Snack bar}

Perbedaan proporsi tepung kacang merah pratanak dan tepung ubi jalar ungu secara signifikan mempengaruhi kadar amilosa Snack bar. Rata- rata kadar amilosa pada Snack bar dapat dilihat pada Tabel 2.

Tabel 2

Kadar Amilosa Snack bar

\begin{tabular}{|c|c|c|}
\hline $\begin{array}{c}\text { Proporsi tepung kacang merah pratanak:tepung } \\
\text { ubi jalar ungu pada Snack bar }\end{array}$ & $\begin{array}{c}\text { Rata-rata } \pm \text { SD } \\
(\%)\end{array}$ & P-Value \\
\hline $30: 70(n=4)$ & $7,10 \pm 0,03^{\mathrm{a}}$ & \\
\hline $20: 80(n=4)$ & $7,88 \pm 0,20^{\mathrm{b}}$ & $<0.01$ \\
\hline $10: 90(n=4)$ & $9,33 \pm 0,28^{\mathrm{c}}$ & \\
\hline
\end{tabular}


Kadar amilosa Snack bar tertinggi pada proporsi kacang merah pratanak : ubi jalar ungu sebesar 10\%:90\%. Semakin banyak proporsi tepung ubi jalar ungu, yang digunakan, maka kandungan amilosa Snack bar semakin meningkat. Hal ini terjadi karena kadar pati pada ubi jalar ungu pekat lebih tinggi yaitu sebesar $74,57 \%$, sedangkan kadar pati pada kacang merah berkisar 25,49\%, dengan masingmasing kadar amilosa sebesar 30-40\%. Semakin tinggi kadar pati, kandungan amilosa semakin meningkat (Ratnaningsih dan Marsono., 2013; Ding et al., 2021).

Proses pratanak yang meliputi perendaman, pemanasan dan pendinginan kembali dapat menyebabkan terbentuknya pati teretrogradasi yang bersifat tidak larut atau biasa disebut dengan pati resisten. Amilosa merupakan jenis pati resisten yang paling stabil (Mustikaningrum, 2011). Kacang merah telah diberi perlakuan pratanak, tetapi, karena tingginya kadar pati ubi jalar ungu, maka peningkatan proporsi kacang merah pratanak yang tinggi (30\%:70\%) kadar amilosanya lebih rendah dibandingkan dengan Snack bar dengan proporsi ubi jalar yang tinggi (10\%:90\%).
Rantai amilosa yang lurus mudah terdegradasi. Ketika rantai amilosa bergabung kembali (retrogradasi) dapat membentuk sebuah polimer yang kompak dan sulit di hidrolisis enzim pencernaan, sehingga akan membentuk pati resisten III (Ratnaningsinh dan Marsono., 2013). Xue et al. (2018) menyebutkan bahwa peningkatan kadar pati resisten pada perendaman dan perebusan kentang, kadar amilosanya lebih tinggi, dibandingkan tanpa pemasakan. Salah satu penelitian menunjukkan bahwa pati resisten III dari tepung cassava yang mengalami proses pemanasan dan pendinginan dapat mengontrol gula darah puasa dan pula darah postpandrial tikus diabetes (Widiastani et al., 2018).

\section{Daya Terima Snack bar}

Pengujian daya terima dilakukan pada 30 orang panelis semi terlatih menunjukkan bahwa tidak terdapat perbedaan yang signifikan antara warna, aroma, rasa, dan tekstur $(\mathrm{P}>0.05)$, akan tetapi secara keseluruhan Snack bar dengan proporsi kacang merah pratanak dan ubi jalar ungu 10:90 lebih disukai dibandingkan dengan proporsi lainnya $(\mathrm{P}=$ 0.04) (Tabel 3). 
Tabel 3

Daya terima Snack bar kacang merah pratanak dan ubi jalar ungu

\begin{tabular}{llllll}
\hline $\begin{array}{l}\text { Proporsi tepung kacang merah } \\
\text { pratanak: ubi jalar ungu }\end{array}$ & Warna & Aroma & Rasa & Tekstur & Keseluruhan \\
\hline $\mathbf{3 0 : 7 0}$ & & & & & \\
$\mathbf{2 0 : 8 0}$ & $3.47 \pm 0.57$ & $3,70 \pm 0,70$ & $3,27 \pm 0,82$ & $3,07 \pm 0,58$ & $3,27 \pm 0,58^{\mathrm{a}}$ \\
$\mathbf{1 0 : 9 0}$ & $3,60 \pm 0,62$ & $3,70 \pm 0,70$ & $3,37 \pm 0,85$ & $3,43 \pm 0,81$ & $3,57 \pm 0,67^{\mathrm{ab}}$ \\
P-Value & $3,80 \pm 0,71$ & $3,67 \pm 0,66$ & $3,53 \pm 0,81$ & $3,50 \pm 1,00$ & $3,67 \pm 0,66^{\mathrm{b}}$ \\
\hline
\end{tabular}

Proporsi tepung kacang merah pratanak: tepung ubi jalar ungu dalam persen (\%). Jumlah panelis sebanyak 30 orang panelis semi terlatih. Uji statistic menggunakan One-way ANOVA, yang apabila signifikan berbeda dilanjutkan dengan uji Post Hoc Duncan Test dengan huruf yang berbeda menunjukkan signifikansi pada $P$ value $<0,05$.

Snack bar dengan proporsi kacang merah pratanak yang lebih rendah lebih disukai dibandingkan dengan proporsi tinggi kacang merah pratanak mungkin disebabkan karena kacang-kacangan memiliki aroma dan after taste yang lebih langu yang menyebabkan produk akhir kurang diterima masyarakat (Inyang et al., 2018). Tingginya proporsi ubi jalar ungu dibandingkan tepung kacang merah pratanak diduga dapat mengurangi rasa dan aroma langu dari kacang merah pratanak, sehingga lebih disukai oleh panelis. Iassanova et al., (2009) menyatakan bahwa enzim lipoksigenase yang tinggi pada kacang-kacangan dapat menghidrolisis lemak, sehingga timbul aroma dan rasa langu pada kacang kedelai. Hal ini mungkin terjadi pula pada Snack bar tinggi kacang merah pratanak yang memiliki aroma dan rasa lebih langu. Secara statistik tidak ada perbedaan kesukaan aroma dan rasa pada ketiga Snack bar, namun secara keseluruhan Snack bar tinggi proporsi ubi ungu lebih dipilih oleh panelis. Selain itu, Fatmala dan Adi (2017) menyatakan bahwa tingginya tepung ubi jalar meningkatkan kerenyahan pada produk biskuit dengan substitusi ubi ungu dan isolat protein kacang kedelai. Pada penelitian tersebut juga dikemukakan bahwa kadar pati yang tinggi pada ubi ungu dapat mengikat air pada saat proses gelatinisasi, sehingga menyebabkan biskuit menjadi renyah. Hal serupa mungkin terjadi pada Snack bar dengan proporsi kacang merah pratanak dan ubi ungu 10:90. Proporsi ubi ungu yang lebih tinggi memberikan tekstur yang lebih renyah. Teori ini didukung penelitian Wulandari (2017) yang menyatakan bahwa food bar dengan proporsi ubi ungu dan kacang merah pratanak (90:10) memiliki daya patah yang lebih tinggi dibandingkan food bar dengan proporsi ubi ungu yang lebih rendah. Daya patah yang tinggi berbanding lurus dengan kerenyahan. 
Evaluasi

organoleptik

menunjukkan bahwa kesukaan warna Snack bar pada tepung ubi ungu 90\% tidak berbeda secara signifikan dibandingkan dengan Snack bar dengan kandungan ubi ungu $70 \%$ dan $80 \%$. Hal ini kemungkinan disebabkan karena Snack bar pada ketiga proporsi memiliki warna hampir sama

\section{KESIMPULAN DAN SARAN}

Pembuatan Snack bar dengan proporsi kacang merah pratanak dan ubi jalar ungu mempengaruhi kadar antosianin, kadar amilosa dan daya terima Snack bar. Snack bar dengan proporsi kacang merah pratanak : ubi jalar ungu $=10: 90$, memiliki kadar antosianin, kadar amilosa dan daya terima tertinggi dibandingkan proporsi lainnya, sehingga formula ini cocok sebagai makanan selingan bagi penderita diabetes mellitus.

Tingginya kadar antioksidan antosianin dan pati resisten tersebut, perlu dilakukan penelitian lanjutan tentang intervensi Snack bar ini kepada penderita diabetes mellitus.

\section{DAFTAR PUSTAKA}

Amalia, R. 2011. Kajian Karakteristik Fisikokimia Dan Organoleptik Snack bar Dengan Bhan Dasar Tepung Tempe dan Buah Nangka Kering Sebagai Alternatif Pangan $C F G F$. Skripsi. Surakarta: UNS coklat kehitaman yang disebabkan karena reaksi maillard. Seperti yang dikemukakan oleh Fatmala dan Adi (2017) dan Fairus et al. (2021) bahwa biskuit dari ubi ungu dan kacang-kacangan memiliki warna kecoklatan akibat reaksi non enzimatis pada proses pemanasan tinggi.

Avianty Selma, Fitriyono Ayustaningwarno. 2013. Kandungan Zat Gizi dan Tingkat Kesukaan Snack bar Ubi Jalar Kedelai Hitam Sebagai Alternatif Makanan Selingan Penderita Diabetes Mellitus Tipe 2. Journal of Nutrition College, Volume 2, Nomor 4, Tahun 2013, Halaman 622-629

Apriyantono, A., D. Fardiaz, N.L. Puspitasari, Sedarnawati, dan S. Budijanto. 1998. Petunjuk Laboratorium Anlisis Pangan: PAU Pangan dan Gizi-IPB. Bogor

Castro-Acosta, M. L., Lenihan-Geels, G. N., Corpe, C. P., \& Hall, W. L. 2016. Berries and anthocyanins: Promising functional food ingredients with postprandial glycaemia-lowering effects. Proceedings of The Nutrition Society; 75, 342e355.

Franz M. 2012. Medical Nutrition Therapy for Diabetes Mellitus and Hypoglicemia of Nondiabetic Origin In: Mahan LK, Escott-stump $S$, Janice LR, editors. Krause's Food, Nutrition, and Diet Therapy 13th Edition. Philadelphia: WB Saunders Company. p. 675-708

Guo H, Ling W. 2015. The update of anthocyanins on obesity and type 2 diabetes: experimental evidence and clinical perspectives. Rev 
Endocr Metab Disord. 2015

Mar;16(1):1-13. doi:

10.1007/s11154-014-9302-z.

PMID: 25557610.

Eleazu Chinedum Ogbonnaya. 2016. The concept of low glycemic index and glycemic load foods as panacea for type 2 diabetes mellitus; prospects, challenges and solutions. African Health Sciences; Vol 16 Issue 2

Fairus Adienda, Hamidah Nanik, Setyaningrum Ira Yahmi. 2021. Substitusi tepung terigu dengan tepung ubi ungu dan tepung kacang tanah pada pembuatan cookies: Kajian kadar protein dan mutu organoleptik. Jurnal Health Care Media Vol 5; 16-22

Fatmala Ayuni Iga, Adi Catur Annis. 2017. Daya terima dan kandungan protein biskuit substitusi tepung ubi jalar ungu dan isolate protein kedelaiuntuk pemberian makanan tambahan ibu hamil kek. Jurnal Media Gizi Indonesia Vol.12; 156163

Gowd Vemana, Jia Zhenquan, Chen wei. 2017. Anthocyanins as promising molecules and dietary bioactive components against diabetes- $A$ review of recent advances. Trends in Food Science and Technology 68; 1-3

Hardoko, Liana Hendarto, dan Tagor MS. 2010. Pemanfaatan Ubi Jalar Ungu (Ipomeabatatas L. Poir) Sebagai Pengganti Sebagian Tepung Terigu dan Sumber Antioksi dan Pada Roti Tawar. Jurnal Teknologi dan Industri Pangan. Vol. XXI (1): 25-32

Hoover, R., T. Hughes, H.J. Chung, Q. Liu. 2010. Composition, Molecular Structure, Properties, and Modification of Pulse Starches: A
Review. Food Research International; 43: 399-413.

Husna El Nida, Melly Novita, Syarifah Rohaya. 2013. Kandungan Antosianin dan Aktivitas Antiokksidan Ubi Jalar Ungu Segar dan Produk Olahannya. Agritech: Vol.33, No3.

lassonova, Diliara \& Johnson, Lawrence \& Hammond, Earl \& Beattie, Samuel. 2009. Evidence of an Enzymatic Source of off flavors in "Lipoxygenase-Null" Soybeans. JAOCS, Journal of the American Oil Chemists' Society. 86. 59-64. 10.1007/s11746-008-1314-y. The utilization of soybean products as food ingredients and foods is often limited by their beanygrassy flavor

Inyang E Ufot, Daniel A Etini and Bello A. 2018. Production and Quality Evaluation of Functional Biscuits from Whole Wheat Flour Supplemented with Acha (Fonio) and Kidney Bean Flours. Asian Journal of Agriculture and Food Sciences; Volume 06 - Issue 06, (ISSN: 2321 - 1571)

Jayaprakasam, B., Vareed, S. K., Olson, L. K., \& Nair, M. G. 2015. Insulin secretion by bioactive anthocyanins and anthocyanidins present in fruits. Journal of Agricultural and Food Chemistry; $53,28 \mathrm{e} 31$.

KhooHock Eng, Azrina Azlan, Sou Teng Tang a and See Meng Lim. 2017. Anthocyanidins

and anthocyanins: colored pigments as food, pharmaceutical ingredients, and the potential health benefits. FOOD \& NUTRITION RESEARC; VOL. 61, 1361779. 
Laurentia Mihardja, Uken Soetrisno, Sidartawan Soegondo.2014. Prevalence and Clinical profile of diabetes mellitus in productive aged urban Indonesia. J. Diabetes Invest ;5507-512

Mustikaningum Fitriana. 2011. Pengaruh Pratanak Kacang Kapri (Pisum sativum axiphium L) Terhadap Kadar Serat Pangan dan Pati Resisten serta Sifat Hipoglikemiknya Pada Tikus Diabetik Induksi Alloksan. Thesis.Program Studi IImu dan Teknologi Pangan Jurusan IImuIlmu Pertanian Program Paska Sarjana UGM. Yogyakarta.

Nintami AL, Rusanti N.2012. Kadar serat, aktivitas Antioksidan, Amilosa dan Uji Kesukaan Mi Basah dengan Subtitusi Tepung Ubi Jalar Ungu (Ipomoea batatas var Ayumurasaki) bagi Penderita Diabetes Mellitus Tipe 2. Journal of Nutrition College; 1:486-504

Ratnaningsih N dan Marsono. 2013. Potensi Fungsional Resistant Starch Tipe 3 dari KacangKacangan dengan Perlakuan Autoclaving Multi siklus Untuk Pencegahan Diabetes Mellitus Tipe II. Laporan Tahunan Penelitian Hibah Bersaing.

Ratseewoa J, F.J. Warrenb, S. Siriamornpun. 2019. The influence of starch structure and anthocyanin content on the digestibility of Thai pigmented rice. Food Chemistry 298; 124949.

Salim Marniati, Abdi Dharma, Elida Mardiah, Ghifarizka Oktoriza. 2017. Pengaruh Kandungan Antosianin dan Antioksidan Pada Proses Pengolahan Ubi Jalar.Jurnal Zarah, Vol. 5 No. 2;
Halaman 7-12 p-ISSN: $2354-7162$

| e-ISSN: 2549-2217

Sancho, R. A. S., \& Pastore, G. M. 2012. Evaluation of the effects of anthocyanins in type diabetes. Food Research International; 46, $378 \mathrm{e} 386$

Sari Ni Made Rizka Erwinda, Ni Wayan Wisaniyasa, A. A. I. Sri Wiadnyani.2020. Studi Kadar Gizi, Serat dan Antosianin Tepung Kacang Merah dan Tepung Kecambah Kacang Merah (Phaseolus vulgaris L). Jurnal $\begin{array}{lll}\text { Itepa,9 (3).282-290 ISSN:2527- } & \end{array}$ 8010

Shaw JE, Sicree RA, Zimmet PZ. 2010. Global estimates of the prevalence of diabetes for 2010 and 2030. Diabetes Res Clin Pract; 87: 4-14.

Shehzad Aamir, Umer Masood Chander, Mian Kamran Sharif1, Allah Rakha, Anam Ansari, Muhammad Zuhair Shuja. 2015. Nutritional, functional and health promoting attributes of red kidney beans; A review. PAK. J. FOOD SCI., 25(4) : 235-246 ISSN: 2226-5899

Widiastini Ariani T, Sakinah Nurus Elly, Nurdian Yudha, Firdaus Jauhar. 2018Type 3 Resistant starch effect of Cassava on Fasting Blood Glucose in Diabetes Mellitus Wistar Rat Model. Journal of Agromedicine and Medical Science; Vol 4No 3.doi: 10.19184/ams.v4i3.6469

Widowati. 2009. Tepung Aneka Umbi sebuah Solusi Ketahanan Pangan. Balai Besar Penelitian dan Pengembangan Pascapanen Pertanian. Jakarta

Williams, Margareth. 2001. Food experimental perspective 
Worldstad, R.E. 2001. Handbook of Food Analytical Chemistry.page 19-31. Wiley-Interscience, New York

Wulandari Anggraini.2017. Pengaruh proporsi tepung ubi jalar ungu dan tepung kacang merah pratanak pada oembuatan food bar terhadap daya patah dan daya terima. Skripsi: Universitas Muhammadiyah Surakarta

Xue Zhuo, Mariette Andersson, Roger Andersson. 2018. Resistant starch and other dietary fiber components in tubers from a high-amylose potato, Food Chemistry, Volume 251, Pages 5863,ISSN 0308-8146, doi $: 10.1016 /$ j.foodchem.2018.01.02

8.

Yamuangmorn Supaporn, Bernard DELL, Chanakan PROM-U-THAI.2018. Effects of Cooking on Anthocyanin Concentration and Bioactive Antioxidant Capacity in Glutinous and Non-Glutinous Purple Rice.Rice Science, 25(5): 270-278

Yi Ding, Maike Wang, Yi Shen, Xiaoli Shu, Dianxing $\mathrm{Wu}$, Wenjian Song. 2021. Physiochemical Properties of Resistaant Starch and Its Enhancement Approaches in Rice. Rice Science, 28 (1):3142.doi;10.1016/J.rsci.2020.11.005 